\title{
Dossiê
}

\section{Entre massas afônicas e o interesse soberano: Fernando Henrique Cardoso e a gênese marxista da teoria do populismo no Brasil}

\author{
Amidst aphonic masses and the sovereign interest: \\ Fernando Henrique Cardoso and the Marxist genesis \\ of the populism theory in Brazil
}

\author{
Pedro Luiz Lima \\ Professor adjunto, Universidade Estadual de Londrina (UEL), \\ Londrina, PR, Brasil \\ pedrollima@gmail.com
}

\begin{abstract}
Resumo: A teoria do populismo erige-se como paradigma hegemônico de interpretação do Estado Novo e da República de 1946 tendo como obras-síntese os clássicos estudos de Octávio lanni e Francisco Weffort, formulados após o golpe de 1964. Seguindo a hipótese de que sua gênese deve ser buscada em disputas político-ideológicas no interior da esquerda que marcaram o período de 1961-1964, o presente artigo argumenta que a obra de Fernando Henrique Cardoso nesta conjuntura constitui um relevante, ainda que pouco estudado, ponto de ancoragem para a devida compreensão da história da teoria do populismo. Bem compreendidos os fundamentos marxistas desta obra, especificamente o modo como algumas noções desenvolvidas por Karl Marx são apropriadas pelo autor de "Empresário industrial e desenvolvimento econômico", abre-se a possibilidade de inscrevê-lo na linhagem dos teóricos do populismo a partir de suas concepções críticas sobre a "democracia como entorpecimento", a "passividade das massas", a "inconsciência de classe" e o "colapso necessário" do "sistema de conciliações" do governo de João Goulart. Ao retomar a inscrição política conjuntural da gênese de tal linhagem, trata-se de empreender um movimento analítico de suspeição com relação à propalada neutralidade axiológica da teoria do populismo - suspeição cujas implicações extrapolam o restrito âmbito dos debates sobre a "história dos conceitos", alcançando também um momento histórico em
\end{abstract}


que, após décadas de elaborações críticas sobre os limites daquela teoria, é notável uma tendência de retomada de seus controversos fundamentos teórico-políticos em diversas e influentes análises sobre o período de 2003-2016.

Palavras-chave: Teoria do populismo; Disputas político-ideológicas; Fernando Henrique Cardoso; Marxismo.

\begin{abstract}
The populism theory emerges as a hegemonic interpretative paradigm of both "Estado Novo" and the "Republic of 1946", whose major works are the classic studies developed by Octávio lanni e Francisco Weffort after 1964's coup d'état. Building upon the hypothesis that its genesis should be searched in the political-ideological disputes that took place within the Left in the 1961-1964 period, this article argues that Fernando Henrique Cardoso's work, although not frequently studied in this particular sense, constitutes a departure point for a proper understanding of populism theory's history. Through the understanding of his work's Marxist foundations, especially with regards to "Empresário industrial e desenvolvimento econômico" (1964), it is plausible to inscribe Cardoso in a lineage of populism theoreticians, as becomes evident in his use of critical notions such as "democracy as numbness", "masses' passivity", "class unconsciousness" and the "necessary collapse" of João Goulart's "conciliatory system". The article affirms a conjunctural political inscription of those lineage's genesis and undertakes an analytical movement of suspicion with regards to the axiological neutrality of populism theory. This suspicion reaches not only the conceptual history debates, but also a precise historical moment in which, after decades of critique on populism theory's limits, there appears to be a revival of its controversial political-theoretical foundations in many influential analyses about Brazilian recent history (2003-2016).
\end{abstract}

Keywords: Populism theory; Political-ideological disputes; Fernando Henrique Cardoso; Marxism.

\title{
Introdução
}

Tem-se vivido no Brasil, já há mais de uma década, uma conjuntura pródiga de reaparições teóricas e conceituais, na esteira do que seria um presente frequentemente interpretado (e vivenciado) na chave da repetição. Ao menos desde 2003, com a ascensão de Luís Inácio Lula da Silva à Presidência da República e com o início dos governos liderados pelo Partido dos Trabalhadores, são corriqueiras as leituras que vinculam a realidade política do país ao contexto do Estado Novo, da República de 1946 e até mesmo da Ditadura Militar no período em que esteve sob a direção do General Geisel. Via de regra, tais interpretações da política nacional utilizam-se da noção de "populismo" para caracterizar, sempre de modo depreciativo, a persistência de uma relação política que seria típica do período histórico que se inicia com o Estado Novo, em 1937, e se encerra com o Golpe de 1964, pondo fim àquela que foi sintomaticamente denominada como a República Populista. A leitura do presente à luz deste malfadado passado adquire ainda novos estímulos, uma vez concretizado o Golpe Jurídico-Parlamentar de 2016 que destitui Dilma Rousseff da Presidência da República: guardadas as devidas proporções, 
T\&P Entre massas afônicas e o interesse soberano: Fernando Henrique Cardoso e a gênese marxista da teoria do populismo no Brasil

o desfecho ilegítimo, em um como no outro caso, indicariam a natureza semelhante de um processo político, o populismo, determinado essencialmente por limites precisos?.

O sentido desta retomada do populismo enquanto categoria analítica explicita-se pela reiteração, na atual análise de conjuntura, de algumas de suas implicações mais relevantes: manipulação das massas; consciência deformada dos verdadeiros interesses de classe; continuidade autoritária; desvalorização das instituições democráticas; limites objetivos da política de conciliação de classes; tendência natural ao colapso do regime. Todos esses componentes fazem-se presentes, em maior ou menor medida, em uma incorporação da"teoria do populismo" que atravessa campos disciplinares, frequentando as análises de filósofos (ARANTES, 2004, 2007; SAFATLE, 2015, 2016), cientistas políticos (BOITO JUNIOR; SAAD-FILHO, 2015) e sociólogos (OLIVEIRA, 2003, 2007; BRAGA, 2012; ANTUNES, 2015) dentre os mais influentes intelectuais da esfera pública nacional.

Uma apreciação detida destas leituras não consta dentre os restritos fins a que se propõe este artigo, mas a aludida retomada contemporânea da "teoria do populismo" e a ilustração da intensidade com que se realiza atualmente essa reprodução nos importam, antes, por embasarem a premissa que o sustenta: neste quadro, o imperativo de revisitar os fundamentos daquela teoria não se justifica apenas para uma necessária reconstrução histórica de seu processo de formação, historiograficamente válida por si mesma, mas também porque recuperar alguns traços pouco explorados dessa história pode, a esta altura, conter a salutar externalidade de lançar luz sobre eventuais pontos cegos das inúmeras tentativas de atualização daquela presumida teoria.

As célebres obras que buscaram desconstruir e invalidar algumas das bases da "teoria do populismo"(VIANNA, 1976; GOMES, 2001, 2005) configuram o pano de fundo dos argumentos avançados neste artigo, assim como os bem-sucedidos esforços de sistematização crítica da história do populismo no Brasil (FERREIRA, 2001; MAIA, 2001; BARBOSA FILHO, 1980). Nosso ponto de partida, especificamente, é a afirmação de que "[...] o formato acadêmico [da teoria do populismo] remete às divergências ideológicas no interior da esquerda na antevéspera de 1964." (GUIMARÃES, 2001, p. 171). Trata-se, portanto, no que segue, de recuperar um relevante fragmento daquela conjuntura de

1 A caracterização do Impeachment sofrido por Dilma Rousseff como um "Golpe Parlamentar"e/ou"Jurídico"e, portanto, como um desfecho ilegítimo de seu segundo mandato na Presidência da República apoia-se no diagnóstico de alguns dos mais relevantes scholars que tomam a política brasileira como objeto de estudo, tais como Leonardo Avritzer (2017), Luís Felipe Miguel (2016), Wanderley Guilherme dos Santos (2017), Ruy Braga (2016) e André Singer (2016), dentre tantos outros. 
acirramento ideológico para perceber como de divergências, desenvolvidas no calor das disputas, fez-se um paradigma historiográfico predominante que soube ocultar sua gênese ideológico-política sob as vestes de uma teoria consolidada a posteriori:

Creio que esta interpretação - a derrota de um processo de democratização - foi a predominante entre os que sofreram a derrota de 64. No pós-64, contudo, e firmando-se como cânone historiográfico nos anos 70 e 80, uma interpretação diversa se impõe. Não só diversa, mas radicalmente oposta. Pois, afinal, houve democracia no período? Não, não houve. Na realidade o que se verifica é a continuidade transformada de um autoritarismo. (GUIMARÃES, 2001, p. 170).

Se a teoria clássica do populismo no Brasil, consubstanciada nas obras de Octávio lanni $(1968,1974)$ e de Francisco Weffort $(1978)$, promove este deslocamento identificado por Cesar Guimarães, em que o Golpe de 1964 deixa de ser interpretado como "derrota da democratização"e passa a ser naturalizado como"colapso do populismo", apenas mais uma das modulações de nosso renitente passado autoritário, é crucial determinarmos, seguindo as trilhas abertas pelo texto seminal supracitado, alguns dos momentos de formação desta teoria - momentos relativamente ignorados pela historiografia crítica do populismo.

Para tanto, parte-se da hipótese de que a obra de Fernando Henrique Cardoso imediatamente anterior a 1964 constitui um destes momentos em que se é capaz de flagrar, a um só tempo, o enraizamento marxista e a imediata inscrição conjuntural de vários dos componentes que depois viriam a compor a"teoria do populismo". Ainda que se pudesse buscar os nexos objetivos que vinculam a obra de Cardoso aos trabalhos posteriores de seu aluno (Weffort) e de seu colega (lanni), não se trata aqui de percorrer este caminho, o que exigiria uma leitura cruzada e a exegese das obras em questão e excederia os limites deste artigo. Aqui, trata-se antes de destacar o sentido comum que aquela obra partilha com os fundamentos conceituais da teoria, na medida mesma em que sintetiza uma tomada de posição que será determinante para a posterior cristalização da noção de populismo.

Como em Fernando Henrique Cardoso (assim como em lanni e Weffort) o ponto de partida para o tratamento da questão do desenvolvimento nacional reside na recepção de determinadas categorias marxistas, partiremos a seguir (I) de uma breve apresentação de alguns marcos do tratamento dispensado por Marx à questão da 
T\&P Entre massas afônicas e o interesse soberano: Fernando Henrique Cardoso e a gênese marxista da teoria do populismo no Brasil

relação entre capitalismo e Estado-nação, a partir dos quais se poderá situar tanto (II) a crítica radical de Fernando Henrique Cardoso, de inícios de 1962, à democracia como "fator de entorpecimento", quanto (III) os temas fundamentais desenvolvidos por sua argumentação em "Empresário Industrial e desenvolvimento econômico no Brasil", formulada em 1963, e que põem o terreno comum teórico-conceitual em que se erigirá a"teoria do populismo".

\section{(I) Fundamentos do antinacionalismo marxista}

A crônica de Fernando Henrique sobre as desventuras do processo de formação da burguesia na periferia do capitalismo se realiza nos marcos conceituais do marxismo. E ao menos desde Capitalismo e escravidão no Brasil meridional, tese defendida em 1961, trata-se de um marxismo cuja fonte fundamental é a obra de Marx. O autor não precisa remeter diretamente a $O$ Capital para que a relação se faça evidente - ainda que não seja pouco emblemático o fato de a "Conclusão"de sua tese de livre docência (defendida em novembro de 1963 e publicada como livro em 1964 sob o título Empresário industrial e desenvo/vimento econômico no Brasil) se iniciar com três longas e destacadas citações do Livro III. Em grande medida, o antagonismo que se estabelece entre o sociólogo uspiano e os adeptos do desenvolvimentismo deve-se à subsunção das categorias de nação e interesse nacional ao conteúdo estritamente marxista das noções de classe, interesse e concorrência. De nossa parte, a leitura que empreenderemos do texto de Fernando Henrique também deve sua inteligibilidade aos vínculos entretecidos com certos conceitos de Marx, de modo que tomaremos como ponto de partida algumas coordenadas por ele desenvolvidas.

Como se sabe, Marx não deixa de conferir validade à tese de que as oscilações da "livre concorrência" determinam a dinâmica do mercado na sociedade capitalista - o que se inverte é o conteúdo da "liberdade" subjacente ao uso do termo pela economia política, assim como as consequências harmônicas que espontaneamente derivariam do entrechoque de interesses. Extrair da bellum omnium contra omnes do mercado a realização necessária da totalidade dos interesses privados (die Gesamtheit der Privatinteressen), que assim se configurariam em um interesse comunitário ou geral (gemeinschaftliche oder allgemeine), constitui dedução abstrata que, para Marx, obscurece o real sentido da 
livre concorrência. Longe da "pretensa forma absoluta da livre individualidade", através da concorrência se revelaria a forma como a sociedade capitalista se reproduz por um mediador multilateral (allseitigem Vermittler), o valor de troca, que relaciona os interesses privados pelo conflito. Enquanto interesse socialmente determinado, o interesse privado não espelha a "livre individualidade", mas sim as condições sociais que o determinam e que independem da consciência dos indivíduos envolvidos. "A dependência recíproca e multilateral de indivíduos mutuamente indiferentes (gegeneinander gleichgültigen Individuen) forma sua conexão social"e se expressa através da mediação do valor de troca - de modo que no capitalismo o indivíduo carrega no bolso seu nexo com a sociedade (seinen Zusammenhang mit der Gesellschaft). O interesse seria, assim, o correlato subjetivo do valor de troca: onde este é, ou tende a ser, o mediador universal de todas as relações, o interesse constitui o móbil generalizado da ação social e o vértice da conexão social, tanto mais eficaz à medida que pressupõe e se realiza através da mútua indiferença. Chega-se através dessa mediação a uma identidade que se forma contraditoriamente pelo conflito e que permanece, portanto, fora do alcance da consciência dos agentes, transformados em pessoas privadas (der Privaten) que apenas se reconhecem nesta condição. A contradição se consuma quando estes seres privados, indivíduos mutuamente indiferentes que se pensam (e são considerados pela economia política como) portadores últimos da "livre individualidade", terminam por "negar e extinguir toda individualidade e peculiaridade" de suas atividades, subsumidas ao nivelador universal do valor de troca (MARX, 2011, p. 104-105, 546-547).

A identidade de interesses dá conteúdo à formação das classes. Como elas apenas se formam pela indiferença e através da concorrência, tem-se nova contradição no fato de que esta identidade de classe, uma "irmandade prática" (praktische Brüderschaft) gerada "enquanto tudo vai bem" nos momentos de expansão do mercado, pode tornar-se seu avesso ao sabor das circunstâncias. A "luta da concorrência" (der Konkurrenzkampf) faz com que, nos períodos de recessão, a "divisão das perdas" traga à tona uma efetiva oposição (Gegensatz) que subsiste entre cada capitalista individual e a classe capitalista como um todo (MARX, 2008, p. 332).

Na decisiva passagem do Livro III em que passa em revista a ideologia mercantilista, Marx dá algumas pistas sobre o modo como concebe a relação entre os interesses da classe capitalista e as atividades do Estado-nação. Identificado o papel desempenhado pelo Estado na "criação acelerada das condições do modo de produção capitalista", 
T\&P Entre massas afônicas e o interesse soberano: Fernando Henrique Cardoso e a gênese marxista da teoria do populismo no Brasil

constata-se que "o caráter nacional do mercantilismo não é mera frase na boca de seus porta-vozes" (MARX, 2008, p. 1040). Por trás das preocupações com a riqueza da nação subjaz a afirmação dos interesses da classe capitalista como "fim último do Estado"(den letzten Staatszweck), ao mesmo tempo em que os ideólogos mercantilistas estão cônscios de que a efetiva "preponderância nacional (des nationale Übergewichts) na sociedade moderna" tem como único fundamento "o desenvolvimento dos interesses do capital e da classe capitalista" (MARX, 2008). Não há, portanto, em Marx um interesse nacional propriamente dito - este aparece apenas como interesse cifrado do capital, o que também se evidencia em seu opúsculo "Bastiat e Carey", publicado como parte do conjunto de textos reunidos nos Grundrisse. Tratado por Marx como o "único economista original dentre os norte-americanos", Henry Carey torna-se objeto de crítica por empreender algo como uma economia política nacionalista. Nesse sentido, o americano aparece na caracterização de Marx como a caricatura da miopia nacionalista, para quem a suposta harmonia das relações sociais capitalistas no interior das fronteiras nacionais deveria ser protegida das desarmonias destas mesmas relações em suas plenas manifestações no mercado mundial. Interessa, aqui, reter a crítica à suposta "ingenuidade" (Naivetät) do protecionismo, que postula o isolamento nacional como se a ameaça à harmonia do livre mercado viesse não de suas próprias categorias contraditórias, mas antes das ameaças externas. Considerar o Estado como "o último refúgio das harmonias econômicas"implica, portanto, abstrair do fato de que o mercado mundial é a "forma mais desenvolvida" (entwickeltsten Form) das relações econômicas capitalistas (MARX, 2011, p. 30-31). Transparece desta polêmica a aversão de Marx a um nacionalismo que, em última análise, representaria adesão aos pressupostos falsamente harmônicos do capital e sua ingênua positivação na esfera limitada de um único Estado. Decorre dessa crítica antinacionalista a consideração das ambivalências do mercado mundial e de suas dissoluções, que importa citar por extenso porquanto deixa entrever certa pulsão dialética de reconciliação a partir da qual a positividade da expansão do capital emerge com nitidez:

Para ele [Carey], a concentração do capital no interior de um país e o efeito dissolvente dessa concentração só têm aspectos positivos. Mas é desarmônico o monopólio do capital concentrado inglês com seus efeitos dissolventes sobre os pequenos capitais nacionais de outros povos. O que Carey não compreendeu é que essas desarmonias do mercado mundial são unicamente as expressões adequadas últimas [die letzten adäquaten Ausdrücke] das 
desarmonias que são fixadas nas categorias econômicas como relações fixas ou que têm uma existência local em menor escala. Não surpreende que, por outro lado, ele esqueça o conteúdo positivo desses processos de dissolução [den positiven Gehalt dieser Auflösungsprozesse] - o único aspecto que examina das categorias econômicas em sua forma abstrata ou das relações reais no interior de determinados países, das quais as categorias são abstraídas em sua manifestação plena no mercado mundial [in ihrerweltmarktlichen, vollen Erscheinung vergißt]. Por isso, onde as relações econômicas se apresentam a ele em sua verdade, i.e., em sua realidade universal, Carey passa de seu otimismo por princípio [prinzipiellen Optimismus] para um pessimismo exasperado e denunciante [einen denunzierenden und gereizten Pessimismus]. (MARX, 2011, p. 30-31).

A ênfase no "conteúdo positivo dos processos de dissolução" levados a cabo pelo processo de expansão do mercado mundial remete ao célebre escrito sobre a dominação britânica na Índia, onde Marx credita aos mais violentos métodos da colonização um positivo efeito civilizatório e "regenerativo"2. Contrapor-se à "realidade universal" das relações econômicas capitalistas em defesa de um "bloqueio nacional à força" (MARX, 2011, p. 30), como postula Carey, seria supor o "capitalismo em um só país", postulação que combinaria o pior da apologética da economia política com o pior da abstração a-histórica. Desse modo, vemos no trecho destacado um Marx que se reconcilia, em alguma medida, com as desarmonias e dissoluções do mercado mundial - âmbito onde tendem a aparecer as "expressões adequadas últimas" daquelas desarmonias e, portanto, onde elas podem ser suprassumidas. A presunção de uma suprassunção nacional das desarmonias postas pelas relações capitalistas equivaleria, caso ultrapassasse a mera ingenuidade, a "decretar a mediocridade universal" (die allgemeine Mittelmässigkeit dekretieren), como diz Marx em outro contexto (MARX, 2003, p. 875).

\section{(II) A crítica radical da democracia como entorpecimento}

A tese que dá origem a Capitalismo e escravidão mal acabara de ser defendida e já no mês seguinte, em novembro de 1961, seria aprovada nas instâncias burocráticas da USP a criação do Centro de Sociologia Industrial e do Trabalho (CESIT), vinculado à

\footnotetext{
2 Os textos de Marx sobre a "revolução social" causada pela invasão britânica da Índia, escritos em 1853 para o New York Daily Tribune, são perfeitamente condizentes, a nosso ver, com os desdobramentos conceituais dos Grundrisse e de O Capital. E interessam enquanto evidências da reconciliação dialética implícita em boa parte da obra de Marx. De modo que os efeitos da indústria inglesa na Índia são "aterradores", mas não deixam de ser "resultado orgânico do atual sistema de produção"; são "destrutivos", mas não deixam de "demonstrar em proporções gigantescas as leis orgânicas imanentes da Economia Política"; são "bárbaros", mas não deixam de "[...] criar as condições materiais para um novo mundo do mesmo modo como as revoluções geológicas criaram a superfície da terra." (MARX, 1975, p. 366-367).
} 
T\&P Entre massas afônicas e o interesse soberano: Fernando Henrique Cardoso e a gênese marxista da teoria do populismo no Brasil

Cadeira de Sociologia I de Florestan Fernandes. Seguindo, em boa medida, os moldes do Laboratoire de Sociologie Industrielle organizado por Alain Touraine e pelo grupo da revista Sociologie du travail, o CESIT é formado com dotações da recém-criada FAPESP e de um convênio articulado por Fernando Henrique com a Confederação Nacional da Indústria $(\mathrm{CNI})^{3}$. Como sabemos, mesmo em meio às teses sobre escravidão e questão racial que centralizam seus trabalhos ao longo da década de 1950, o grupo de Florestan não deixava de atentar para (e de produzir artigos sobre) o tema do subdesenvolvimento no Brasil. A criação do Centro visa, pois, a concentrar esses esforços e simboliza o momento em que se torna prioritário para o grupo de pesquisadores fundamentar (ainda que empiricamente) uma sociologia do desenvolvimento.

Fernando Henrique dirigirá o CESIT até abril de 1964. Após o golpe, o Centro se enfraquece em seu papel de núcleo de pesquisa e reduz-se à função de formar quadros para posterior efetivação na carreira de docentes da USP (ROMÃO, 2006, p. 138). Sobre a breve vida ativa do CESIT, pode-se afirmar sem margem de dúvida que seu principal resultado foi a tese de livre-docência de seu diretor, Empresário industrial e desenvolvimento econômico no Brasil. Neste momento de sua obra, como sabemos, a inflexão dialética de Fernando Henrique está plenamente consumada, de modo que chamam a atenção as significativas dissonâncias que se manifestam entre sua tese sobre o desenvolvimento e o conteúdo dos textos elaborados por Florestan como pontos de partida dos trabalhos do CESIT. Com efeito, esta disparidade reforça os argumentos pela relativização da unidade que frequentemente se confere à "escola sociológica paulista"e, por consequência, pela atribuição de certa singularidade ao marxismo de Fernando Henrique.

Note-se sumariamente que Florestan exibe, nos referidos textos, diversos dos traços dualistas que caracterizam sua obra do período. Não é preciso, e nem convém a nossos fins, avançarmos em sua exegese para perceber a reincidência da linguagem dos padrões, ritmos e obstáculos quando se concebe uma "[...] análise dos influxos negativos ou positivos de fatores extra-econômicos na configuração do padrão e do ritmo da industrialização" (FERNANDES, 1962a, p. 358); ou, ainda, quando se trata de

[...] focalizar e analisar como a ausência de requisitos estruturais e funcionais, de natureza psicossocial e sócio-cultural, tem-se refletido e tenderá a refletir-se em nossas tentativas de implantar uma economia capitalista no Brasil. (FERNANDES, 1962b, p. 334-335).

3 Sobre a astúcia política de Fernando Henrique no momento de criação do CESIT, cf. Romão (2006, p. 111 e segs.), que se dedica exclusivamente ao estudo do Centro. 
Enfim, também o CESIT carrega consigo a marca da sobreposição entre o funcionalismo de sua maior referência intelectual e o marxismo de seu diretor.

Por ora, para restituir o sentido da obra de Fernando Henrique no tumultuoso contexto político que estamos a considerar, tomaremos como atalho o pequeno texto do início de 1962 que se constitui como um dos poucos escritos do sociólogo que intermedeiam as defesas de suas duas teses ${ }^{4}$. A nosso ver, este que poderia passar despercebido como texto menor da prolífica obra de Fernando Henrique desponta como objeto de destacado relevo para o propósito de interpelar o sentido político de sua sociologia - e sua leitura lançará luz sobre alguns pontos em que a perspectiva de Cardoso (1964) se faz ambígua.

Em "Subdesenvolvimento e sociedade de massas" (escrito para o ll Congresso Brasileiro de Sociologia), a crítica às instituições da democracia representativa é direta, assim como a desconfiança com relação a seu específico modo de funcionamento nas sociedades subdesenvolvidas. Certo ímpeto insurreicionista parece determinar o tom adotado de um modo absolutamente inédito com relação ao restante da obra do sociólogo, conferindo-Ihe um caráter excepcional que não suprime do texto sua relevância. Pelo contrário, pensamos que tal excepcionalidade antes expressa o momento histórico específico de sua formulação - e ainda que Fernando Henrique não trate diretamente do Brasil, parece-nos evidente que o contexto imediato de crise política determina e radicaliza o conteúdo de suas proposições e de algumas de suas conclusões.

É da relação entre capitalismo e democracia que se trata - e aqui, como se verá, afastaremo-nos resolutamente da moderação pecebista, das esperanças reformistas de Celso Furtado e da convergência técnica entre capitalismo e socialismo defendida por Hélio Jaguaribe. O ponto de partida do argumento de Fernando Henrique consiste no diagnóstico de que está "enterrada a democracia liberal" com a transformação monopolista do capitalismo concorrencial (CARDOSO, 1962b, p. 142). No mundo das grandes corporações e da "sociedade de massas", a falsa ilusão do "capitalismo democrático das sociedades anônimas" logo se desfaz na percepção do estrito controle exercido por "grupos minoritários de proprietários e rentistas". Em outros termos, quer isto dizer que

4 Nos dois anos que separam as defesas de Capitalismo e escravidão (outubro de 1961) e de Empresário industrial (novembro de 1963), Fernando Henrique ainda publica ligeiro texto sobre "Educação e mudança social"(1962), onde reproduz a leitura dualista dos "aspectos educacionais negativos" como "fatores de atraso cultural"; e artigo sobre a história do Brasil Meridional ("Dispersão e unidade: Rio Grande do Sul e Santa Catarina"), publicado em 1963 na História Geral da Civilização Brasileira, coletânea organizada por Sérgio Buarque de Holanda. 
T\&P Entre massas afônicas e o interesse soberano: Fernando Henrique Cardoso e a gênese marxista da teoria do populismo no Brasil

"[...] o quadro otimista quanto à capacidade de modificação essencial do capitalismo e de sua superação não revolucionária pelo 'capitalismo social [...]'" constituiria mera ideologia em vias de ser plenamente desmistificada pela análise sociológica (CARDOSO, 1962a, p. 143). Apenas uma transformação de caráter revolucionário poria em risco "o fundamento do capitalismo, a propriedade privada dos meios de produção"- e, neste quadro, o crescimento econômico e o "progresso crescente", longe de induzir a qualquer tipo de transformação estrutural, antes fomentam uma maior participação no consumo cujo correlato necessário seria "um processo de alienação em escala jamais suspeitada", um "alheamento da massa dos problemas relativos ao controle do poder político" (CARDOSO, 1962a, p. 145). A pujança material do Welfare State nos países centrais do capitalismo teria correspondência política em uma "[...] adesão maciça de toda a população à moral e aos objetivos dos grupos dominantes [...]" (CARDOSO, 1962a, p. 147), de modo que, para além da alienação, não resta qualquer função a ser atribuída às instituições democráticas:

Entretanto, o alheamento das massas e sua manipulação através dos mass media permitiu que entre o Poder e as massas houvesse um vácuo preenchido apenas pelos grupos ligados à propriedade (proprietários ou agentes da propriedade privada): a máquina partidária, a imprensa, os meios de comunicação em geral, extinguiram na moderna sociedade capitalista de massa qualquer possibilidade de influência ativa das camadas populares sobre as questões básicas que dizem respeito aos destinos da sociedade global porque destruíram o próprio ponto de partida para isto: a consciência da situação real de dominação. (CARDOSO, 1962a, p. 146-147).

Alienadas, manipuladas e inconscientes, as "massas"seriam promovidas ao consumo e destituídas, no mesmo ritmo, de "qualquer possibilidade" de consciência política. Não resta dúvida: estamos diante de perspectiva que se situa no campo da esquerda radical. E que não se furta, ademais, a assegurar a "diferença essencial" que distinguiria as massas socialistas de suas congêneres capitalistas: aquelas"[...] não [seriam] socializadas de forma a alhearem-se dos problemas do controle político." (CARDOSO, 1962a, p. 148).

Caso o artigo se mantivesse nesse registro, de crítica ao moderno funcionamento das democracias de massa no contexto do capitalismo de Welfare State, já nos seria proveitoso pela rara manifestação de radicalidade que, por si só, denota uma tomada de posição revolucionarista. A análise da falência das democracias capitalistas ultrapassa, 
contudo, esse registro e abarca a especificidade do funcionamento das instituições democráticas nos países subdesenvolvidos. Se estas portam efeitos trágicos mesmo lá onde são originais, não poderiam deixar de ser farsescas onde não passam de repetição. Daí a peremptória afirmação:

[...] a história do capitalismo não se repete: as classes típicas da sociedade capitalista, burguesia e proletariado se formam noutro contexto histórico e não épossivel manter [nos países subdesenvolvidos] as instituições e os mecanismos clássicos de pressão política vigentes naquelas áreas: democracia representativa, partidos tipicamente de classes urbanas, sindicatos preocupados com reivindicações político-econômicas, etc. (CARDOSO, 1962b, p. 151).

A afirmação de uma impossibilidade é qualificada, na sequência do texto, e as instituições democráticas passam a ter, nos países subdesenvolvidos da América Latina, uma "significação funcional" distinta. Não é que sua existência seja impossível - ela é apenas diferente. E ainda mais precária. Pois uma vez destituída dos impulsos dinâmicos de um "proletariado urbano", das "aspirações de liberdades públicas oriundas das populações citadinas" e do "maior ímpeto de transformação" que caracteriza a "tradição urbano-proletária" europeia, a realidade dos países subdesenvolvidos tenderia a assimilar a democracia como mera "engrenagem de acomodação social" (CARDOSO, 1962b, p. 152-153). Neste contexto, "aperfeiçoar os aspectos formais da democracia" pode apenas implicar um reforço da "[...] influência dos grupos dominantes minoritários sobre o comportamento das massas [...]" (CARDOSO, 1962b, p. 152). Não há alternativa dentro da ordem, parece afirmar Fernando Henrique (no Brasil de inícios de 1962, vale lembrar) - e o consumo de massas consiste em outro "mecanismo de preservação da dominação". A saída seria, enfim, uma mobilização que vem de fora e não se deixa integrar nos aparatos institucionais. Tudo que vincula "as massas" ao Estado, todas as mediações reconhecidas por este como legítimas, até mesmo a realização dos "anseios de progresso material" das massas - tudo deve ser desmistificado como "fator de entorpecimento". As expressivas asserções aparecem condensadas no trecho seguinte:

Neste contexto, os impulsos de reorganização social têm maiores chances de êxito no sentido de modificações profundas na estrutura de poder, e, correlatamente, de alterações na correlação de forças das classes sociais, exatamente quando é possível somar às inquietações a "mobilização" crescente das massas urbanas sem a correspondente 
T\&P Entre massas afônicas e o interesse soberano: Fernando Henrique Cardoso e a gênese marxista da teoria do populismo no Brasil

"integração" destas camadas no jogo político-partidário estatal-legal. Inversamente, quando as massas urbanas podem realizar seus anseios de progresso material e exprimir dentro da ordem estabelecida seu ponto de vista no que diz respeito ao processo político geral (pela organização, por exemplo, de partidos populares-nacionalistas) e podem expor suas reivindicações sobre as condições de trabalho (através de sindicatos reconhecidos como legítimos pela sociedade global), elas atuarão como fator de entorpecimento diante das pressões sobre a ordem social formadas a partir dos núcleos dinâmicos não integrados à sociedade urbana de massas. (CARDOSO, 1962b, p. 151).

É evidente que o tom quase jacobino não permanecerá no texto que consagra a livre-docência de Fernando Henrique. De todo modo, algo desta exclamativa negação da "ordem estabelecida", desta sintomática aversão aos "partidos populares-nacionalistas" e desta difusa conclamação à mobilização em nome de "modificações profundas na estrutura de poder" - algo disto permanece subjacente às profundas estruturas de Empresário industrial e desenvolvimento econômico no Brasil. Desde já, registre-se uma impressão que deverá ser corroborada pela sequência da análise: a recusa absoluta da efetividade de qualquer possível transformação política a partir de instâncias"integradas à ordem", em sua aparência revolucionária, talvez seja a contraparte de uma perspectiva que, ao enraizar os "impulsos dinâmicos" da sociedade no movimento imanente do desenvolvimento capitalista, tende no limite a sublimar a esfera da política num opaco plano de indeterminação.

\section{(III) Passividade de massa, inconsciência de classe e necessidade do colapso}

Definidos brevemente, na seção I acima, os termos em que Marx almeja invalidar as postulações nacionalistas, podemos enfim retomar o marxismo de Fernando Henrique em um dos momentos-chave de sua afirmação política antinacionalista. Como se sabe, a pesquisa de Cardoso (1964) tem como ponto de partida a tese do PCB sobre a centralidade da burguesia nacional no processo de desenvolvimento econômico do país - o que fundamentaria tanto sua teoria dos resíduos feudais quanto sua prática aliancista e antiimperialista. Em Cardoso (1964, p. 74), volta-se o foco para"[...] o papel dos empreendedores no desenvolvimento econômico dos países subdesenvolvidos [...]", e toda a inquirição buscará decifrar o enigma da burguesia nacional manqué. 
Apesar de o objeto de pesquisa de Fernando Henrique incidir diretamente sobre questões que Ihe são contemporâneas, não estamos, por decerto, distante das preocupações de Capitalismo e escravidão: a especificidade brasileira é estudada, primeiro, pela história das contradições de um capitalismo que se efetiva através de um modo de trabalho supostamente incompatível e, segundo, pela investigação acerca do papel da burguesia no momento posterior daquela história. Se no que tange ao trabalho este capitalismo desventuroso apresenta notáveis discrepâncias e se abre para novas contradições, seria de se esperar dialeticamente que quanto ao capital o mesmo tipo de configurações aparentemente anômalas viesse a se estabelecer. Será, então, que "nos quadros do mercado colonial" a "burguesia' e o 'desenvolvimento' relacionam-se como se fossem um grupo social e sua raison d'être" (CARDOSO, 1964)? Caberá à sociologia, municiada de surveys e afins, passar cientificamente a limpo os fundamentos ideológicos constitutivos da luta política.

Como no artigo de 1962 que percorremos acima, considera-se em Cardoso (1964) o subdesenvolvimento a partir de certas concepções acerca da estrutura do capitalismo em seu estágio monopolista - com a sensível diferença de que, na tese de livre-docência, nota-se manuseio mais frequente das categorias marxistas. A crítica ao suposto caráter democrático das sociedades anônimas reaparece, e volta-se a enfatizar que é "[...] a apropriação privada dos meios de produção e a exploração do trabalho dos não possuidores [...]" que formam a base social para uma atividade empresarial que continuaria a ser movida pelo lucro (CARDOSO, 1964, p. 38). É importante assinalar que no tratamento que dispensa às formas contemporâneas do capital, o argumento de Fernando Henrique, em geral, ressalta o sentido da persistência das relações capitalistas fundamentais sob a variação de suas formas fenomênicas:

À diversificação da camada proprietária pode ter correspondido uma diversificação da camada assalariada, mas salário, lucro e renda continuaram a ser a expressão econômica das formas básicas de relações sociais da sociedade capitalista contemporânea. O que equivale a dizer que estas se mantêm nas sociedades capitalistas industriais modernas como relações de superposição e dominação de umas classes sobre outras, em que pese as formas modernas que a exploração econômica e a dominação social assumiram na sociedade industrial de massas. (CARDOSO, 1964, p. 38). 
T\&P Entre massas afônicas e o interesse soberano: Fernando Henrique Cardoso e a gênese marxista da teoria do populismo no Brasil

A exploração econômica continua, pois, a ser o substrato disseminado do capitalismo, malgrado suas novas formas, e não é desimportante que a utilização do termo expressão econômica retoma termos caros às formulações de Marx, como no próprio trecho destacado acima de sua crítica a Carey, em que as desarmonias do mercado mundial são"expressões adequadas últimas" de "desarmonias fixadas nas categorias econômicas". Aqui, mais uma vez, o fato de que Fernando Henrique escreve sem conhecer este específico texto de Marx reforça o ponto: a remissão a "salário, lucro e renda" (preço também poderia ter sido incluído na lista) como "formas básicas de relações sociais na sociedade capitalista contemporânea" tem sentido evidente de reiteração do núcleo categorial de O Capital, assim como a recorrência de certa hermenêutica das expressões. Antes, portanto, de tratar das especificidades do capitalismo monopolista e do subdesenvolvimento, o sociólogo determina as coordenadas conceituais que direcionam sua interpretação - e esta anterioridade possui evidente sentido normativo.

Quanto ao subdesenvolvimento, Fernando Henrique busca, no mesmo espírito de sua tese de doutoramento, esclarecer que não se trata de um tipo alheio à sociedade capitalista. O "capitalismo escravocrata" do Brasil oitocentista não deixa, como vimos, de ter seu conteúdo determinado pelas relações e categorias capitalistas. De modo análogo, o subdesenvolvimento "[...] não equivale ao não desenvolvimento em geral, mas, ao contrário, é uma forma de exprimir a existência de um tipo de desenvolvimento". Considerado em chave dualista, prevaleceria a definição de uma externalidade entre desenvolvimento e subdesenvolvimento; na dialética marxista de Fernando Henrique, contudo, são as "[...] relações básicas entre estas duas formas de sociedade que, em conjunto, exprimem o modo capitalista de produção [...]" (CARDOSO, 1964, p. 74). Assim, tanto os esquemas classificatórios abstratos de W. Rostow, quanto as teorias funcionalistas da modernização com sua ênfase na transição das sociedades tradicionais para a modernidade, são deslocadas pelo que se concebe como uma "visão caleidoscópica do processo de mudança social" (CARDOSO, 1964, p. 65).

A continuidade com Capitalismo e escravidão também se nota na recorrência da tensão, que permanecerá sempre irresoluta, entre a consciência dos agentes e o dinamismo semiautomático das categorias do sistema capitalista. Por um lado, afirma-se que a crescente burocratização das empresas tenderia a dissociar o potencial de inovação das "[...] qualidades pessoais" de empreendedores individuais - afinal, "[...] o capital, 
não o capitalista, detém o segredo que explica o sistema [...]" (CARDOSO, 1964, p. 31). Até este ponto, parece afirmar-se apenas o primado da objetividade de relações que ultrapassariam o nível da consciência dos agentes. Mas, por outro lado, "o capital nada mais é do que a expressão de um modo de relação entre os homens" - e pretende-se então reforçar o lugar da atividade consciente no desenrolar dos eventos históricos, invertendo a lógica da expressão: antes se tratava de conceber o capital como substância das interações, agora parece se tratar de tomar a relação entre os homens como substância a ser exprimida pelo capital. Mas há uma indisfarçada tautologia, que viola a inversão pretendida, quando se afirma que "o capital expressa um modo de relação": de fato, o capital expressa o modo capitalista de relação, que se antepõe e sobredetermina a consciência dos sujeitos históricos, quer o chamemos de capital, quer o chamemos de modo capitalista de relação. Desta forma, a relação entre os homens cujo papel histórico se queria reativar diante do império do capital permanece ofuscada, no trecho, pela inadvertida interposição de um modo que embute aquilo que se queria ultrapassar. A passagem é curiosa, ademais, porque culmina com expressiva alusão a Hegel, em que mais uma vez os termos parecem trair os propósitos do escritor:

[...] a ação dos homens de empresa e a consciência que têm de seu papel não se relacionam com o"sistema capitalista"como a Filosofia para Hegel se relaciona com a vida. Não surgem à cena como a Filosofia que chega "com sua luz crepuscular a um mundo já a anoitecer, quando uma manifestação de vida está prestes a findar". Ao contrário, são a vida do capitalismo. O modo de empreender e a ideologia do empreendedor realizam e exprimem a produção, a distribuição e a acumulação, tal como são tornadas possíveis num dado momento do desenvolvimento social. (CARDOSO, 1964, p. 45).

O que começa como uma afirmação da ação e da consciência dos "homens de empresa", que seriam a vida do capitalismo, termina como seu oposto: ação e consciência se transmutam em "modo de empreender" e "ideologia do empreendedor", e por fim aquela vida não passa de uma expressão da "produção, distribuição e acumulação". Repõe-se o ponto de partida de que se pretendia escapar - "o começo é fim" (der Anfang Zweck ist) (HEGEL, 1992, p. 32).

A argumentação de Fernando Henrique não é, contudo, economicista. O principal atributo do capitalismo monopolista, a seu ver, é deixar às claras a tendência de "politização da economia" que seria, em princípio, um efeito necessário do sistema (CARDOSO, 1964, 
T\&P Entre massas afônicas e o interesse soberano: Fernando Henrique Cardoso e a gênese marxista da teoria do populismo no Brasil

p. 41-42). "Política e economia tornaram-se a mesma coisa" com o surgimento do modo capitalista de produção, e a superação da forma concorrencial substitui a "inovação no plano da empresa ou do mercado"pelo"fiat da decisão política"(CARDOSO, 1964, p. 41 e 79). Se em sua reprodução o modo monopolista recorre cada vez mais aos recursos do Estado e as elites econômicas estão crescentemente entrelaçadas com as elites políticas, mantém-se necessária a "mediação das lutas políticas" para a transformação estrutural do "sistema vigente de apropriação" (CARDOSO, 1964, p. 39). Opondo-se a Schumpeter (e a Jaguaribe), o marxista recusa as versões da "morte técnica e não política" do sistema de livre empresa e insiste que apenas um "movimento político" seria capaz de alterar as bases de funcionamento deste sistema. Mas a politização da economia não tem como corolário uma politização da sociedade. Neste ponto, pelo contrário, os termos usados serão praticamente os mesmos dos que acompanhamos em "Subdesenvolvimento e sociedades de massa". A concepção de Estado do sociólogo será, aqui, em tudo oposta à que vimos se desenvolver na perspectiva de Furtado - e vemos a aparição, no discurso de Fernando Henrique, do célebre "Estado comitê executivo" do Manifesto Comunista:" [...] é preciso que a nação se veja representada no Estado e sinta as decisões deste como expressão da vontade coletiva, embora, de fato, o Estado continue a ser, nas resoluções fundamentais, instrumento da prosperidade dos capitalistas [...]" (CARDOSO, 1964, p. 42). As decisões empresariais e a lógica de comando do mercado "politizam-se", o que não implica a politização do Estado: este permanece instrumentalizado pela dominação de classe.

Resta saber se esta classe teria os atributos e a capacidade, no caso brasileiro, para fazer do Estado um comitê executivo para seus negócios. A anatomia da burguesia brasileira se realiza em Cardoso (1964) a partir de dois eixos: no primeiro, Fernando Henrique busca salientar a especificidade da burguesia em contexto de subdesenvolvimento e dissocia, assim, sua perspectiva das análises que se fazem nos parâmetros dualistas explícitos na noção de atraso cultural. No segundo eixo, deslocam-se os termos da questão ideológica vigente e a nacionalidade da burguesia torna-se secundária diante da questão decisiva acerca de sua racionalidade.

De início, os aparentes traços de irracionalidade no comportamento do empresariado parecem remissíveis às "condições peculiares do processo de industrialização do Brasil" (CARDOSO, 1964, p. 113). Tais peculiaridades - o acanhamento do mercado, as flutuações de oferta e procura, o alto impacto das decisões governamentais, a conjuntura de altos 
lucros e a "concorrência relativamente frouxa" - induziriam à persistência de um controle familiar das empresas, posto que o "controle direto dos negócios" constituiria possível vantagem para a necessária tomada rápida de decisões. No subdesenvolvimento, portanto, o que seria fator de atraso e resistência à mudança torna-se comportamento relativamente adequado, não ao modelo universal de gestão capitalista racional, e sim a um contexto específico. A irracionalidade é racional e eficaz onde a previsibilidade é escassa, e a sensibilidade dialética ensina assim, mais uma vez, a desconfiar das avaliações imediatas do fosso que separaria o atraso do moderno. No mercado brasileiro, "a racionalização das formas de controle pode resultar em perdas graves", enquanto os "modos irracionais de conceber o trabalho e a vida econômica" podem ser "favoráveis para a formação de empresas modernas" (CARDOSO, 1964, p. 114 e 146).

A constatação das contradições da especificidade não implica que nosso autor esteja prestes a decretar a eterna enecessária persistência da mediocridade do capitalismo nacional. Nossa leitura deverá, neste ponto, acompanhar como a argumentação de Fernando Henrique atravessa o diagnóstico da irracionalidade para então, apesar (ou por causa) de sua cautela dialética, reconsiderar as especificidades como limites da burguesia nacional e, assim, postular o espírito de concorrência e o interesse como, a um só tempo, conteúdos necessários da constituição geral da classe burguesa e tendências intrínsecas de seu comportamento subdesenvolvido. Será preciso atentar para a dupla desconstrução da categoria pecebista de burguesia nacional: no limite, para Fernando Henrique, ela nem é propriamente burguesa, ainda que deva (e tenda a) ser, e nem é nacional (posto que o aburguesamento vem de fora). Quando ela permanece"nacional", inscrita nas especificidades protoburguesas do contexto do subdesenvolvimento, ela ainda não é burguesia; quando ela se fizer burguesia, ela já terá deixado de ser (se é que algum dia tenha efetivamente sido) nacional.

O paralelo com o tratamento dado em Capitalismo e escravidão pode novamente nos ser útil. A detecção da especificidade do capitalismo escravocrata não obstrui a percepção dialética que nota a incontornável tendência da superação desta forma inferior pelas relações de trabalho assalariado. Se bem lembramos, neste processo de superação a concorrência entre os charqueadores escravocratas e o trabalho livre dos saladeros platinos deteve centralidade - não havia como manter-se a escravidão uma vez estabelecidos o contato e a competição com uma produção via trabalho assalariado. 
T\&P Entre massas afônicas e o interesse soberano: Fernando Henrique Cardoso e a gênese marxista da teoria do populismo no Brasil

A dissolução do hibridismo tornou-se inevitável. De modo análogo, no caso da mentalidade empresarial irracional da "burguesia nacional", a saída do impasse se dá pela imposição sistêmica do desenvolvimento capitalista: ainda que os capitães-de-indústria tradicionalistas de São Paulo, assim como os estancieiros gaúchos, estivessem aquém de seu próprio interesse de classe - este se impõe com férrea necessidade. O que, por si só, não implicaria um nivelamento das formas capitalistas de desenvolvimento, mas sim a superação de uma especificidade por outra. Vejamos, pois, como isto que poderíamos chamar de um paradigma do interesse soberano se desenvolve no texto de Empresário industrial subordinando o âmbito da política e revelando algumas raízes do que viria posteriormente a se constituir como uma "teoria" do populismo5.

Sabemos que"a difusão do controle familiar direto", símbolo máximo de uma gestão empresarial vinculada à tradição (e à irracionalidade econômica), difundiu-se não por uma patologia atávica da cultura nacional, e sim porque era estruturalmente determinada pelas peculiaridades da economia brasileira como "condição de sobrevivência" para muitas empresas (CARDOSO, 1964, p. 129). Tais peculiaridades possibilitariam a obtenção de altos lucros aliados a baixos padrões tecnológicos, o que desvincularia "o objetivo do lucro" do "desenvolvimento da base técnica de produção" e amorteceria assim "o sentido da produção capitalista desenvolvida" (CARDOSO, 1964, p. 137). A existência, particularmente nas regiões mais pobres do país, de "áreas de consumo protegidas da concorrência" distorceria "as potencialidades reais de crescimento industrial", tornando "racionais" (lucrativas) as práticas empresariais mais tradicionais (irracionais) (CARDOSO, 1964, p. 136 e 137). Até aqui, estamos no conhecido terreno de um diagnóstico dialético da irracionalidade. A transição argumentativa deste diagnóstico para a postulação normativa da "dinamização" da atividade empresarial insinua-se com a crítica à "consciência muito limitada dos capitães-de-indústria", que enxergariam a "ação oculta do 'comunismo"' em qualquer mero avanço da "modernização do comportamento operário"(CARDOSO, 1964, p. 140). E cristaliza-se na identificação do industrialismo nacionalista como uma artimanha para assegurar baixos padrões de concorrência:

5 A expressão "interesse soberano" deriva do título de uma obra de Fréderic Lordon (2011). O sentido que atribuímos aqui, porém, não guarda maiores relações com o "ensaio de antropologia econômica espinosista" do filósofo francês. Estamos mais próximos do sentido atribuído ao "império do interesse" referido por Vianna (1999, p. 190) no contexto de sua discussão sobre as interpretações weberianas do Brasil . Contudo, trata-se neste artigo de pensar como uma interpretação marxista toma por fundamento o que Vianna chama de "física dos interesses". O modo como essas duas matrizes, a marxista e a weberiana, se relacionariam uma com a outra no pensamento político e social brasileiro, é tema de grande rendimento que não cabe, por óbvio, nos limites deste artigo. 
As significações da ação do dirigente industrial que, no Brasil, está atento às portarias e decretos governamentais e que procura influir junto aos Governos para obter concessões, empréstimos, isenções etc., exprimem-se num contexto social e econômico em que $a$ eliminação da competição é tentada como um recurso para manter níveis tecnicamente insatisfatórios de produção e altos lucros unitários. A defesa desta política é feita em nome da necessidade de construir-se a "indústria nacional", o que se justifica até certo ponto [...], mas os resultados dela ultrapassam frequentemente os propósitos enunciados para se fixarem na manutenção de padrões arcaicos de atividades econômicas. (CARDOSO, 1964, p. 138).

A afirmação de que a defesa da indústria nacional se faz em nome do que seriam os interesses inconfessáveis na perpetuação do subdesenvolvimento por parte de "setores menos dinâmicos" da burguesia parece inverter por completo o sentido do nacional-desenvolvimentismo: pelo ângulo de Fernando Henrique, a"burguesia nacional" (ou ao menos o seu setor "arcaico" predominante) deixa de ser a portadora em potencial do desenvolvimento para ser o agente encapuzado que estorva a modernização industrial do país. E, no mesmo passo, pode-se inferir que as empresas de capital estrangeiro, longe de representarem a negação do autêntico desenvolvimento nacional, se constituirão como agentes dinamizadores do desenvolvimento e da acumulação capitalista no país. Neste registro, o que antes era contenção dialética diante da sobreposição de um modelo de racionalidade a um contexto específico torna-se afirmação da modernização como imperativo.

Assim como vimos, há algumas páginas atrás, uma insuspeita afirmação do conteúdo positivo dos processos de dissolução que se realizam com a expansão do mercado mundial - aqui também o marxista Fernando Henrique parece se insurgir contra as ilusões (e a má-fé) nacionalistas que ignorariam a impossibilidade de isolar a harmonia interna das desarmonias postas pelas próprias relações capitalistas de produção. A especificidade do subdesenvolvimento torna-se limite ao desenvolvimento: tende a ser dissolvido, diria Marx - e será dissolvido. Ea irracionalidade racional torna-se inconsciência de classe. Neste quadro, "[...] as formas de consciência, ação e definição de objetivos políticos, econômicos ou sociais que são encontradiças na burguesia industrial discrepam do que corresponderia a seus efetivos interesses de classe. [...]" (CARDOSO, 1964, p. 170). E evidencia-se, finalmente, que uma classe que não chega a desenvolver "formas de comportamento social compatíveis com sua 'situação de classe'" não poderia possuir a capacidade e os atributos para instrumentalizar o Estado em seu favor (CARDOSO, 1964, 
T\&P Entre massas afônicas e o interesse soberano: Fernando Henrique Cardoso e a gênese marxista da teoria do populismo no Brasil

p. 175 e 176). O argumento do sociólogo por vezes parece subestimar a capacidade política desta burguesia incompleta, em movimento que prenuncia o modo como se delineará sua concepção da participação política das "massas": a despeito da crescente importância econômica, faltaria aos industriais "[...] a socialização necessária para o desempenho dos papéis a que deveriam responder como cidadãos de uma república democrático-burguesa." (CARDOSO, 1964, p. 175).

Mas no discurso dialético trata-se menos de inconsistências do que de efetivas contradições. E as desventuras da burguesia no país exprimem-se como efeito de uma soberania do interesse que termina por fazer do desenvolvimento algo estruturalmente alheio à política do nacionalismo. Nesse sentido, a heteronomia política da burguesia no contexto brasileiro de inícios dos anos 1960, que a mantém sempre aquém da hegemonia de classe e que constitui um dos eixos do populismo, combina-se com o fato da sua dependência econômica. Esta, ainda que não seja aqui desenvolvida como viria a ser em obras posteriores, já aparece como elemento fundamental da análise.

Neste esboço das determinações recíprocas entre os planos interno e externo, a burguesia se veria subordinada como instrumento da dominação dos "grupos tradicionais", oscilando entre estes e as "forças populares", enquanto se transforma concretamente em "sócia menor" de um desenvolvimento nacional cada vez mais determinado pela presença econômica do Estado e do capital estrangeiro (CARDOSO, 1964, p. 188, 191 e 197). A análise de conjuntura de Cardoso tem como ponto de partida a consideração de que com o governo JK se teria estabelecido um "modelo de crescimento industrial"que teve na"inversão maciça de capital estrangeiro" seu ponto de ancoragem (CARDOSO, 1964, p. 87 e 117). Por este modelo, as empresas nacionais teriam sido "praticamente obrigadas" a "manter algum tipo de relação com organizações internacionais"(CARDOSO, 1964, p. 118) - o que revelaria uma primeira imagem, no discurso do sociólogo, da "dependência associada", como transparece do trecho seguinte:

O desenvolvimento industrial no mundo contemporâneo implica na adoção pelos países subdesenvolvidos de práticas de economias de escala, desde o início da industrialização. Estas práticas, por sua vez, dependem da formação de "grandes empresas". Além disso, a penetração das organizações econômicas internacionais nos mercados dos países subdesenvolvidos, quando não os subjuga inteiramente, provoca reações dos empresários nacionais no sentido de garantir o mercado para "grandes empresas" sob seu controle. 
Em geral, como foi o caso do setor privado da economia brasileira, as grandes empresas nacionais acabam por associar-se às empresas estrangeiras de uma ou de outra forma, tornando-se dependentes, na medida em que são sócios menores. (CARDOSO, 1964, p. 156).

Tem-se, pois, que a lógica de desenvolvimento do "mundo contemporâneo"tenderia a subjugar os empresários nacionais. Sua consciência de classe adviria, enfim, não como produto ideológico dos projetos de autonomia nacional, mas sim do próprio exercício da heteronomia. O interesse de classe vem à tona como tendência intrínseca de todo o processo de desenvolvimento e faz-se, enfim, soberano apenas através da dependência: por isso afirma o sociólogo que com "[...] as alianças de grupos industriais brasileiros com grupos internacionais, cada vez mais as diferenças ideológicas entre grupos de industriais tenderão a desaparecer em nome da condição comum de capitalistas." (CARDOSO, 1964, p. 183).

Este parece ser o caminho já sociologicamente delimitado para a formação de um empresariado que, formado por "homens de empresa" racionais, constitui-se e deve constituir-se como o avesso da "burguesia nacional" do PCB. A perspectiva da dialética marxista se põe, assim, em aparente"transcendência" com relação aos conflitos políticos do contexto brasileiro, pois, como sintetiza o crítico literário," [...] contrariamente ao que sustentam os nacionalistas, a reflexão dialética depende da análise formal, cujo referente não é o país do coração, mas o país verdadeiro (o das classes sociais)" (SCHWARZ, 1987, p. 136). Tal pretensão de um formalismo transcendente não implica, contudo, que seja plausível abster-se politicamente dos efeitos antagônicos desta tomada de posição.

A despeito da centralidade que a desmistificação da categoria pecebista detém na argumentação de Cardoso, é evidente que não existem apenas "empresários industriais" no horizonte cartografado pelo sociólogo. O marxismo de Fernando Henrique e sua postulação disso que viemos chamando de interesse soberano incide diretamente na análise da "sociedade de massas". E se o capitão-de-indústria tradicionalista não se constitui propriamente como burguês, também as "massas populares" se definem pelo que (ainda) não são. Nesse sentido, porque "[...] não se transformaram de imediato no proletariado redivivo portador da missão histórica reservada à'classe universal',' as massas populares não passariam de interlocutor afônico da cena política brasileira (CARDOSO, 1964, p. 92, 95). 
T\&P Entre massas afônicas e o interesse soberano: Fernando Henrique Cardoso e a gênese marxista da teoria do populismo no Brasil

A crítica da política brasileira na chave do populismo que se desenvolve em Cardoso (1964) não constitui, como se sabe, uso inaugural do conceito 6 . Para nossos fins, importa identificar não tanto uma instrumentalização imediata do conceito, lateral nesta obra de Fernando Henrique, mas sim uma caracterização da política em que as implicações da noção de populismo aparecem (antes da posterior elaboração da "teoria") como componente fundamental de sua interpretação marxista e como eixo, por vezes menosprezado, da consolidação posterior de um paradigma teórico do populismo que ganharia notoriedade através de outros autores. Por ora, através do populismo esperamos definir o campo de antagonismos, esboçado ao longo da análise precedente, em que se inscreve a posição política, marxista, de Fernando Henrique.

As massas afônicas aparecem como o protagonista passivo desta narrativa sobre a política nacional7. Sem a "sedimentação de uma experiência urbana de vida"e desprovidas do "projeto de controle do processo de mudança" que apenas poderia derivar de uma "situação econômica e social de classe", as massas populares foram "mais estímulo do que agente" da República de 1946 (CARDOSO, 1964, p. 94). Reiterados os termos da crítica à democracia liberal que vimos se afirmar no texto de 1962, Fernando Henrique volta a conceber a ampliação no horizonte de participação política das massas como mero fortalecimento do Estado, da mistificação de uma sempre falseada volonté générale e da manipulação do povo. A continuidade desta radical condenação de uma democracia cuja forma apenas encobriria a substância de um engodo evidencia-se na seguinte passagem:

6 De acordo com alguns levantamentos sobre a história deste conceito, os primeiros autores que teriam adotado, no Brasil, o populismo como categoria de análise política foram Hélio Jaguaribe e Guerreiro Ramos (GOMES, 2001; MAIA, 2001).

7 Em seu pioneiro estudo sobre a "teoria do populismo", Rubem Barbosa Filho (1980) destaca que tanto os teóricos latino-americanos (Torcuato DiTella e Gino Germani) quanto os brasileiros (Weffort, lanni, Moisés, dentre outros) fariam um uso da noção de populismo que se fundamenta nas teorias da sociedade de massas de Arendt, Michels, Ortega y Gasset, entre outros. Barboza Filho adota, em geral, uma perspectiva em que a teoria da sociedade de massas parece ser dotada de "pressupostos estranhos ao marxismo" (BARBOSA FILHO, 1980, pp. 175, 181 e 185). Por esse viés, haveria uma "contradição insanável" entre o marxismo e a teoria da sociedade de massas enquanto "matriz de pensamento liberal-democrático", que repercutiria na "desfiguração e (no) enrijecimento de categorias centrais do marxismo" (BARBOSA FILHO, 1980, p. 177) - e, assim, seriam as inconsistências deste marxismo desfigurado que deveríamos inventariar. A nosso ver, contudo, parece mais afim ao espírito de contradição com que buscamos interpretar o marxismo de Fernando Henrique admitir que as duas vertentes, supostamente heterogêneas, guardam uma relação no interior deste marxismo - o que, ademais, parece ser sugerido pelo próprio Rubem Barboza Filho quando afirma que "[...] os pensadores que deram forma às análises populistas no Brasil acabaram por fixar, no interior do horizonte marxista, as limitações específicas da visão liberal-democrática sobre o real." (BARBOSA FILHO, 1980, p. 175). Neste caso, a relação seria contraditória e imanente, e caberia investigar como uma crítica à democracia liberal se combina internamente com os próprios pressupostos do objeto criticado. A instigante tarefa de identificar o modo específico desta interpenetração ultrapassa, porém, os propósitos do presente trabalho. 
Na nova ordem, o Estado, que nunca foi, obviamente, o ponto de encontro neutro do interesse de todos, fortaleceu-se graças ao maior número dos cidadãos engajados como'massa de manobra' dos interesses políticos, mas continuou a ser controlado nas decisões fundamentais pela aliança entre a burguesia industrial e os grupos agrários e financeiros tradicionais, que, por sua vez, exprimem a dominação imperialista e o subdesenvolvimento. [...] Da mesma maneira, a nova ordem não permite mais a exclusão pura e simples do 'ponto de vista popular': razão por que os meios de comunicação de massa passam a ser decisivos para o controle do governo e da Nação. É preciso fazer coincidir a ideia que o povo forma de seus interesses com o interesse dos grupos dominantes para que o Estado possa arrogar-se a legitimidade na defesa da política econômica e da ordem vigente.

Entretanto, a participação das camadas populares no processo político não só é manipulada, em grande parte pelos meios de comunicação de massa, como a ineficácia dos partidos e movimentos políticos organizados foi substituída pela ação de líderes carismáticos e de demagogos que se tornaram veículo de ligação entre o povo e o Estado (CARDOSO, 1964, p. 96).

Não há um "interesse de todos", o "interesse nacional" tampouco passa de uma "abstração" e, por fim, a própria ideia de um desenvolvimento nacional seria apenas um construto ideológico da "[...] liderança intelectualizada e pequeno-burguesa dos movimentos nacionalistas e dos comandos partidários da esquerda." (CARDOSO, 1964, p. 97). Dados a afonia das massas, a inaptidão da esquerda, o enraizamento dos "grupos agrários tradicionais" no interior do Estado e o movimento pendular de uma burguesia cujo efetivo interesse de classe destoa das práticas costumeiras e a faz oscilar entre a hegemonia e a manutenção da ordem: uma vez pintado este quadro, a subsunção da política no populismo se completa pela eficaz, ainda que falsa, mediação do líder carismático e dos demagogos. Através da descrição de Fernando Henrique da conjuntura política - não custa lembrar, mais uma vez, que a tese de livre-docência é defendida em novembro de 1963 e, hoje sabemos, a menos de seis meses do golpe -, somos levados a uma cena onde, como diz Hegel a respeito do verdadeiro, "não há membro que não esteja ébrio" (HEGEL, 1992, p. 46). Neste ambiente, apenas por "delírio direitista" a ideologia burguesa manifesta seu temor da revolução e do povo, transfigurando este em "proletariado revolucionário" (CARDOSO, 1964, p. 189) - assim como seriam vãs as 
T\&P Entre massas afônicas e o interesse soberano: Fernando Henrique Cardoso e a gênese marxista da teoria do populismo no Brasil

esperanças, por outro lado, numa democracia das massas de manobra onde o Estado aparece como ator transcendente a controlar as cordas do jogo de marionetes ${ }^{8}$. Se a política brasileira vacila entre golpes e contragolpes, através da imagem do "populismo esclarecido" transparece a clássica figura do bonapartismo (CARDOSO, 1964, p. 190). A sintomática ocorrência deste conceito e sua vinculação à crítica do populismo ratifica o argumento sobre a substância marxista da interpretação do sociólogo ${ }^{9}$ - e, de fato, a argumentação final de Empresário industrial parece convergir para um novo dezoito de Brumário, repetição da repetição.

Mas aqui, ao contrário da obra clássica de Marx, o autor escreve em meio aos acontecimentos e a conclusão bonapartista da história não pode ser afirmada como fait accompli, mas apenas sugerida. Entre o "populismo esclarecido" aparentemente creditado a João Goulart e a "aspiração bonapartista velada de 'golpes militares'", a burguesia industrial já teria "optado pela ordem" e abdicado da "hegemonia plena da sociedade" - de modo que o sentido do bonapartismo parece indiferente ao sociólogo (CARDOSO, 1964, p. 91 e 198). Neste tom, em face da argumentação desenvolvida acima, sua célebre sentença final pareceria um despropósito, não fosse ela expressiva do lugar de onde parte a análise de Fernando Henrique:

Resta verificar qual será a reação das massas urbanas e dos grupos populares e qual será a capacidade de organização e decisão de que serão capazes para levar mais adiante a modernização política e o processo de desenvolvimento econômico do país. No limite a pergunta será então: subcapitalismo ou socialismo? (CARDOSO, 1964, p. 198).

Assim se encerra o texto, e quando já estamos convencidos da inaptidão afásica das massas para protagonizarem ativamente o jogo político, nosso autor nos desafia a considerar a viabilidade do socialismo como potencial efeito da "organização e decisão" das massas urbanas e grupos populares. A nosso ver, esta crepuscular aparição do

8 A relativa autonomização do Estado que fundamenta a caracterização da "política populista" parece ter, como efeito correlato, a minimização das efetivas diferenças que distinguem os governos ao longo da República de 1946. Como afirma Guimarães, a interpretação do "período populista" pressupõe a"[...] consagração do Estado, não deste ou daquele governo, mas de todos os governos do período." (GUIMARÃES, 2001, p. 170).

9 Os possíveis vínculos entre bonapartismo e populismo foram assinalados no âmbito de um estudo teórico sobre o conceito marxista. Enquanto figura do "estado autônomo", o bonapartismo é"[...] um regime populista e policial. Objetiva manter a ordem para beneficiar a obtenção do lucro pela burguesia, mas impede, ao mesmo tempo, a emergência da democracia liberal. 0 poder é exercido por um ditador e seu entourage mediante a apropriação e a manipulação do aparato burocrático. Suas perspectivas? A oposição futura de todas as classes. Eis o estado autônomo num contexto capitalista. Aqui, a burguesia, como todas as demais classes, não interfere nos negócios do Estado. Abdicou do domínio político." (GUIMARÃES, [20--?], p. 102). 
socialismo estaria a indicar apenas o ponto de partida da posição política do autor - uma vez que, pela sua própria análise, não parece haver lugar para um desdobramento socialista entre as massas afônicas e o interesse soberano. E tanto é assim que, em sua anterior ocorrência no texto de Cardoso (1964), o "socialismo" aparece devidamente desesperançado ${ }^{10}$.

De todo modo, não devem restar dúvidas de que estamos diante de uma interpretação cujos efeitos ultrapassam em muito a estreiteza dos muros da clausura acadêmica - e que se situa, na mais branda das hipóteses, "a meio caminho da intervenção política" (SCHWARZ, 1999, p. 98). São diretas, por exemplo, as alusões ao "neo-schumpeterianismo extemporâneo" de Jaguaribe e às "inconsistências da análise sociológica" de Furtado, cujo economicismo terminaria, para seu crítico marxista, por "[...] retirar da história o nervo político, dando por suposto pacificamente o que não é verdadeiro: que a Civilização industrial destrói a oposição dos interesses de classe e o choque entre as nações" (CARDOSO, 1964, p. 80, 81, 85). Frequente também é a identificação, pelo sociólogo, das "análises da maioria dos autores ligados ao ISEB" com o aliancismo e a definição da burguesia nacional como protagonista do processo de desenvolvimento.

\section{Considerações finais}

Sabemos, enfim, que Fernando Henrique tece uma interpretação que se contrapõe às diversas manifestações do desenvolvimentismo: sua condenação da democracia como populismo o afasta da demofilia afirmada na obra de Álvaro Vieira Pinto ${ }^{11}$; sua compreensão dos fundamentos do capitalismo o distancia do tecnicismo de Hélio Jaguaribe (Jaguaribe, 1962); sua consideração dos limites de uma autonomização do processo de decisões econômicas em países subdesenvolvidos o contrapõe ao nacionalismo de Celso Furtado. Em geral, como vimos, seu marxismo transforma o comunismo do PCB em antagonista preferencial - e, inscrita na dinâmica dos conflitos

100 trecho é o seguinte:"as novas formas de participação política acarretaram problemas de reorganização da vida democrática que, embora não apontem para os caminhos do Socialismo, põem em dúvida a eficácia da democracia tradicional" (CARDOSO, 1964, p. 40).

11 'Nacionalismo de apelo democrático'é expressão estranha - decerto devedora daquele'tempo das ilusões' que a subsequente atemporalidade das certezas científicas haverá de enterrar no cemitério dos populismos". (GUIMARÃES, 2001, p. 164). 
T\&P Entre massas afônicas e o interesse soberano: Fernando Henrique Cardoso e a gênese marxista da teoria do populismo no Brasil

políticos de seu tempo, a análise de Fernando Henrique compartilha afinidades com alguns autores, e atores políticos, que se posicionam sempre à esquerda da esquerda'².

Em registro mais militante, o jovem Wanderley Guilherme dos Santos (1962) afirma em Quem dará o golpe no Brasil que "[...] a democracia, tal como existe, também é uma ditadura" e que, portanto,"[...] a ditadura que ameaça o povo e o governo que possuímos não é a mesma que se dá entre a água e o vinho, mas apenas a que separa um vinho suave de outro, só que mais azedo."(SANTOS, 1962, p. 8). No mesmo diapasão, a prioridade conferida à luta contra o populismo é explicitada em Reforma contra reforma, onde o imperativo é "[...] desmistifi[car] as massas a respeito das medidas apresentadas pelo Governo como audazes e progressistas" e "[...] combat[er] esse populismo tendo em vista conquistar a hegemonia no processo brasileiro." (SANTOS, 1963a, p. 49). De um ponto de vista teórico, a aproximação entre a perspectiva de Wanderley Guilherme e as conclusões de Fernando Henrique aparece de maneira clara em outra obra do período, em que o jovem do ISEB questiona os pressupostos do nacional-desenvolvimentismo, direciona acerbas críticas a Jaguaribe e Furtado e questiona a dualidade nação-antinação em que se fundava a política dos nacionalistas (SANTOS, 1963b, p. 106).

São também consideráveis as afinidades do diagnóstico de Cardoso (1964) com a interpretação de Ruy Mauro Marini (1962), o que se observa, por exemplo, em suas"Reflexões sobre o bonapartismo", texto publicado na Revista Movimento da UNE. Para este autor, o Brasil viveria fase de transição em que a criação de um regime bonapartista aparecia como solução para as alternativas, postas na realidade histórica, de uma democracia socialista e da ditadura militar de direita (MARINI, 1962, p. 13). Segundo Marini, o Luís Bonaparte da vez poderia ser representado por um retorno de Jânio Quadros ou até mesmo por Leonel Brizola13. A consonância entre Fernando Henrique e Marini pode ser, em alguma medida, estendida à Organização Revolucionária Marxista-Política Operária

\footnotetext{
12 Nesse sentido, sobre o contexto posterior à Declaração de Março de 1958 do PCB, afirma Vianna: "Não por acaso é da intelligentsia de São Paulo que virão os fundamentos mais persuasivos em favor da ruptura revolucionária" (VIANNA, 2004, p. 51) - afirmação que se reitera em Lahuerta (2005, p. 177). As ambiguidades da esquerda da esquerda são assinaladas por Cesar Guimarães, que indica as "incômodas semelhanças" entre "direita liberal e esquerda radical"nas posições contrárias ao populismo (GUIMARÃES, 2001, p. 165). Para o mesmo autor, no contexto do imediato pré-golpe," “...] é como se a extremaesquerda só observasse como inimigo o adversário 'populista', descuidando-se da direita, até porque, para alguns, um processo de fusão estaria em andamento." (GUIMARÃES, 2001, p. 173). Sobre a "esquerda uspiana", a interpretação de Emir Sader (2005, p. 174) conclui em direção semelhante: "[...] a falta de hierarquização nos embates concretos entre as classes fazia com que, diante do enfrentamento entre o governo Jango e a direita, se manifestassem sintomas claros de uma equidistância, tal o sentimento de repulsa ao nacionalismo".
}

13 Em texto posterior, Marini (2000, p. 36) atribui a "tendência bonapartista" a João Goulart e à concretização da tese do PCB de um "governo da burguesia industrial apoiado pela classe operária". 
(POLOP), criada em 1961 e que reunia jovens intelectuais dos meios universitário e jornalístico, como o próprio Marini (BADARÓ, 2002, p. 197, 198). Na esquerda da época, a POLOP se distinguia tanto por sua crítica ao diagnóstico do PCB, em que clamava para si os marcos teóricos marxistas, quanto pela afirmação de que, sendo a realidade brasileira caracterizada como plenamente capitalista, a tarefa revolucionária deveria assumir, de imediato, um caráter socialista, em vez de nacional-burguês ${ }^{14}$.

O antagonismo com relação ao paradigma do nacional-desenvolvimentismo lança, enfim, não apenas Fernando Henrique como também grande parte da intelligentsia paulista, a este lugar de aproximação com a extrema esquerda - o que se dá a ver nos textos, escritos em 1963 e publicados em 1965, de Política e revolução social no Brasil (lanni et al., 1965), onde a mesma perspectiva norteia os trabalhos de Octavio lanni, Paul Singer, Gabriel Cohn e Francisco Weffort ${ }^{15}$. Não por acaso, esta obra coletiva assinala uma primeira aparição, em nada extemporânea, do tratamento que Weffort dedicaria ao populismo nos anos subsequentes.

No que tange à obra de Cardoso, a argumentação desenvolvida acima revela, ao menos quanto aos textos diretamente analisados, o modo como nela se pode apreender um momento de substantiva tomada de posição política cujos fundamentos já configuram a substância do que seria posteriormente formalizado como "teoria do populismo". Somos, assim, lançados muito além do horizonte da presumida neutralidade científica com que tantos ainda costumam ler a produção da "escola sociológica paulista" - e pudemos observar detidamente como as bases de uma crítica na chave do populismo se construíram, a partir de uma recepção de Marx e da assunção de diversos antagonismos

$\mathbf{1 4}$ É evidente que essa afinidade entre o grupo revolucionário e as teses de Fernando Henrique se limita ao plano do diagnóstico e não chega a abranger a exortação revolucionária que, após o golpe, adotaria a luta armada como tática política. A possível aproximação não deixa, contudo, de ser sintomática do sentido político da obra de Fernando Henrique no contexto em questão. Dentre as organizações de esquerda críticas ao Partido Comunista, a POLOP se distinguia, por seu autodefinido caráter marxista, tanto da Ação Popular (AP) quanto do stalinismo chinês do PC do B. Questionando uma suposta originalidade da tese de Fernando Henrique, Álvaro Bianchi também assinala a afinidade: "As críticas à noção de 'burguesia nacional'e aos esquemas etapistas que caracterizavam a análise do PCB eram voz corrente na esquerda anti-stalinista da época e, particularmente, na Organização Revolucionária Marxista-Política Operária (Polop)"(BIANCHI, 2010, p. 189).

15 Weffort publica nesta obra - concebida no mesmo momento em que Fernando Henrique concluía “Empresário Industrial e desenvolvimento econômico no Brasil" - o primeiro dos ensaios que compõem O populismo na política brasileira (1978). "Política de massas" termina significativamente com a afirmação de que a realização do "Estado autônomo" se daria como conclusão do populismo - o que parece projetar uma linha de continuidade entre o populismo e seu "colapso": "A revolução democrática populista só estará concluída com o seu próprio desmascaramento; o Estado se projetará como algo superior ao conjunto da sociedade e parecerá dirigi-la soberanamente; esta transformação da imediata representação contraditória do povo parecerá a alguns a realização das aspirações populares; homogeneidade, unidade de comando, eficiência. Necessariamente, porém, as massas não terão participação neste Estado abstrato e ele desvendará, de maneira inevitável, sua natureza de classe." (WEFFORT, 1965, p. 198). 
T\&P Entre massas afônicas e o interesse soberano: Fernando Henrique Cardoso e a gênese marxista da teoria do populismo no Brasil

com os mais variados atores e autores políticos relevantes do período. Resta investigar, alhures, como, através dos estudos sobre a dependência, formulados entre 1965 e 1968, os antagonismos consumarão sua reviravolta e o mesmo marxismo poderá passar da negatividade de sua inscrição antipopulista à positividade da afirmação do desenvolvimento dependente - reforçando, por fim, a intuição de que as ambivalências da dialética podem, sem prejuízo de suas virtudes no trato da contradição, expressar uma curiosa indeterminação política.

\section{Referências}

ANTUNES, R. Fenomenologia da crise brasileira. Lutas Sociais, v. 19, p. 9-26, 2015.

ARANTES, P. E. Zero à esquerda. São Paulo: Conrad Livros, 2004.

ARANTES, P. E. Extinção. São Paulo: Boitempo, 2007.

AVRITZER, L. Entrevista à Revista Carta Capital. Revista Carta Capital, 29 abr. 2017. Disponível em: $<$ https://www.cartacapital.com.br/politica/o-declinio-do-apoio-ao-governo-no-congressovai-se-acentuar>. Acesso em: 11 jan. 2017.

BADARÓ, M. Em busca da Revolução Socialista: a trajetória da POLOP (1961-1967). In: REIS, D. A.; RIDENTI, M. (Ed.). História do Marxismo: partidos e organizações do anos 1920 aos 1960. Campinas: Editora UNICAMP, 2002. p. 197-226. (v. 5).

BARBOSA FILHO, R. Populismo: uma revisão crítica. Dissertação (Mestrado em Ciência Política)Universidade Federal de Juiz de Fora, Juiz de Fora, 1980.

BIANCHI, A. O marxismo fora do lugar. Política e Sociedade, v. 9, n. 16, p. 177-203, 2010.

BOITO JUNIOR, A.; SAAD-FILHO, A. Brazil: the failure of the PT and the rise of the 'New Right'? Socialist Register, v. 52, p. 213-230, 2015.

BRAGA, R. A política do precariado: do populismo à hegemonia lulista. 1. ed. São Paulo: Boitempo, 2012.

BRAGA, R. O fim do lulismo. In: JINKINGS, I.; DORIA, K.; CLETO, M. (Ed.). Por que gritamos golpe? São Paulo: Boitempo, 2016.

CARDOSO, F. H. Subdesenvolvimento e sociedade de massas. Revista Brasileira de Ciências Sociais, v. 2, n. 1, p. 85-106, 1962a.

CARDOSO, F. H. Capitalismo e Escravidão no Brasil Meridional: o negro na sociedade escravocrata do Rio Grande do Sul. São Paulo: Difusão Europeia, 1962b.

CARDOSO, F. H. Empresário industrial e desenvolvimento econômico no Brasil. São Paulo: Difusão Europeia do Livro, 1964.

FERNANDES, F. A empresa industrial em São Paulo (projeto de estudo). In: FERNANDES, F. A sociologia numa era de revolução social. Rio de Janeiro: Zahar Editores, 1962a. p. 338-358. 
FERNANDES, F. Economia e Sociedade no Brasil: análise sociológica do subdesenvolvimento. In: FERNANDES, F. A sociologia numa era de revolução social. Rio de Janeiro: Zahar Editores, 1962b. p. 314-337.

FERREIRA, J. (Ed.). O populismo e sua história: debate e crítica. Rio de Janeiro: Civilização Brasileira, 2001.

GOMES, A. C. O populismo e as ciências sociais no Brasil: notas sobre a trajetória de um conceito. In: FERREIRA, J. (Ed.). O populismo e sua história: debate e crítica. Rio de Janeiro: Civilização Brasileira, 2001. p. 17-57.

GOMES, A. C. A invenção do trabalhismo. Rio de Janeiro: FGV, 2005.

GUIMARÃES, C. Vargas e Kubitschek: a longa distância entre a Petrobras e Brasília. In: CARVALHO, M. A. R. (Ed.). República no Catete. Rio de Janeiro: Museu da República, 2001. p. 155-175.

GUIMARÃES, C. Estudo sobre os regimes autoritários: a contribuição de Marx. Dissertação (Mestrado)Universidade de Chicago, Chicago, [20--?].

HEGEL, G. W. F. Fenomenologia do Espírito. Petrópolis: Vozes, 1992.

IANNI, O. O colapso do populismo no Brasil. Rio de Janeiro: Civilização Brasileira, 1968.

IANNI, O. A formação do Estado populista na América Latina. Rio de Janeiro: Civilização Brasileira, 1974.

IANNI, O. et al. Política e Revolução Social no Brasil. Rio de Janeiro: Civilização Brasileira, 1965.

JAGUARIBE, H. Desenvolvimento econômico e desenvolvimento político. Rio de Janeiro: Fundo de Cultura, 1962.

JAGUARIBE, H. O nacionalismo na atualidade brasileira. Rio de Janeiro: EDUCAM, 2005.

LAHUERTA, M. Em busca da formação social brasileira: marxismo e vida acadêmica. Revista Perspectivas, v. 28, p. 157-186, 2005.

LORDON, F. L'intérêt souverain. Paris: La Découverte, 2011.

MAIA, J. M. E. A história de um conceito: populismo no Brasil. Dissertaçã (Mestrado em Ciência Política)-Instituto Universitário de Pesquisas do Rio de Janeiro, Rio de Janeiro, 2001.

MARINI, R. M. Reflexões sobre o bonapartismo. Revista Movimento, p. 12-15, 1962.

MARINI, R. M. Dialética da dependência. Petrópolis: Vozes, 2000.

MARX, K. La dominación británica en la India. In: MARX, K. Obras escogidas de Marx y Engels. Tomo I. Madrid: Fundamentos, 1975.

MARX, K. O Capital: crítica da economia política. Livro I. Rio de Janeiro: Civilização Brasileira, 2003.

MARX, K. O Capital: crítica da economia política. Livro III. Rio de Janeiro: Civilização Brasileira, 2008.

MARX, K. Grundrisse: manuscritos econômicos de 1857-1858: esboços da crítica da economia política. São Paulo: Boitempo; Rio de Janeiro: Editora UFRJ, 2011.

MIGUEL, L. F. A democracia na encruzilhada. In: JINKINGS, I.; DORIA, K.; CLETO, M. (Ed.). Por que gritamos golpe? São Paulo: Boitempo, 2016.

OLIVEIRA, F. Crítica à razão dualista/O ornitorrinco. São Paulo: Boitempo, 2003. 
T\&P Entre massas afônicas e o interesse soberano: Fernando Henrique Cardoso e a gênese marxista da teoria do populismo no Brasil

OLIVEIRA, F.; RIZEK, C. S. (Ed.). A era da indeterminação. São Paulo: Boitempo Editorial, 2007. discípulos e "um seminário" (1958-1978). Tese (Doutorado em História)-Universidade de São Paulo, São Paulo, 2011.

ROMÃO, W. M. Sociologia e política acadêmica nos anos 1960: a experiência do CESIT. São Paulo: Humanitas/FAPESP, 2006.

SADER, E. Nós que amávamos tanto o capital: fragmentos para a história de uma geração. Sociologias, v. 7, n. 14, p. 150-177, 2005.

SAFATLE, V. P. O mito do desenvolvimento econômico na era Lula. In: SOUZA, P. (Ed.). Brasil: sociedade em movimento. São Paulo: Paz e Terra, 2015. p. 71-76.

SAFATLE, V. P. Entre a oligarquia e o populismo. Folha de São Paulo, São Paulo, 29 abr. 2016.

SANTOS, W. G. Quem dará o golpe no Brasil? Rio de Janeiro: Civilização Brasileira, 1962.

SANTOS, W. G. Reforma contra reforma. Rio de Janeiro: Tempo Brasileiro, 1963a.

SANTOS, W. G. Introdução ao estudo das contradições sociais no Brasil. Rio de Janeiro: Tempo Brasileiro, 1963b.

SANTOS, W. G. A democracia impedida: o Brasil no século XXI. Rio de Janeiro: FGV, 2017.

SCHWARZ, R. Que horas são? Rio de Janeiro: Paz e Terra, 1987.

SCHWARZ, R. Sequências brasileiras. São Paulo: Companhia das Letras, 1999.

SINGER, A. Por uma frente ampla, democrática e republicana. In: JINKINGS, I.; DORIA, K.; CLETO, M. (Ed.). Por que gritamos golpe? São Paulo: Boitempo, 2016.

VIANNA, L. W. Liberalismo e sindicato no Brasil. Rio de Janeiro: Paz e Terra, 1976.

VIANNA, L. W. Weber e a interpretação do Brasil. Revista Novos Estudos, p. 33-47, 1999.

VIANNA, L. W. A Revolução Passiva: Iberismo e americanismo no Brasil. Rio de Janeiro: Revan, 2004.

WEFFORT, F. Política de massas. In: IANNI, O. et al. Política e Revolução Social no Brasil. Rio de Janeiro: Civilização Brasileira, 1965

WEFFORT, F. O populismo na política brasileira. Rio de Janeiro: Civilização Brasileira, 1978.

Recebido: 11 jan., 2017

Aceito: 23 abr., 2017 